\title{
Current problems and tasks of forest protection in Poland
}

\author{
Iwona Skrzecz ${ }^{1} \bowtie$, Aldona Perlińska ${ }^{2}$ \\ ${ }^{1}$ Forest Research Institute, Department of Forest Protection, Sękocin Stary, Braci Leśnej 3, 05-090 Raszyn, Poland, \\ phone: +48 22 7150541, e-mail: i.skrzecz@ibles.waw.pl \\ ${ }^{2}$ General Directorate of the State Forests, Department of Forest Protection, Grójecka 127, 02-124 Warszawa, Poland
}

\section{Abstract}

Current problems of forest protection concern the declining health of forest stands due to climate change and the resulting extreme weather events such as heat waves, droughts, hurricane winds, heavy rainfalls and floods. Repeated impacts of these factors increase susceptibility of forest stands to pest insects and fungal pathogens.

Norway spruce (Picea abies [L.] H. Karst) is sensitive to high air temperatures and water shortage. Long lasting droughts during the last two decades, have been one of the reasons behind Norway spruce dieback due to severe outbreak of European spruce bark beetle Ips typographus (L.) in the mountainous regions of southern Poland. In the Scots pine (Pinus sylvestris L.) stands, water balance disorders have enhanced the colonization of weekend trees by steelblue jewel beetle Phaenops cyanea (F.) and engraver beetle Ips acuminatus (Gyll.), as well as contributed to the spread of fungal diseases caused by Gremmeniella abietina (Lagerb.) Cenangium ferruginosum Fr. and Sphaeropsis sapinea Fr. fungi.

Water related stress leads to weakening of oak stands, which are attacked by Agrilus spp. beetles and pathogens from the genus Phytophthora. It is possible that long lasting droughts initiated the spread of infectious ash disease caused by Hymenoscyphus fraxineus (= Chalara fraxinea), which resulted in the epidemic of ash dieback throughout Europe.

Until recently, the use of plant protection products was the most common method of forest protection against pest insects and pathogens. Poland's accession to the European Union has affected the marketing and use of plant protection products in the country. The implementation of the EU legislation (Directive 91/414/EEC, Directive 2009/128/ EC and Regulation No 1107/2009) has resulted in decreased assortment of pesticides registered for the protection of forests. High costs and long registration process considerably limited the interest of producers in placing the plant protection products on the market. Systematic decrease in the number of plant protection products possible to register for use in forestry, as well as the principles of integrated plant protection established in the EU in 2014 call for seeking plant protection methods based on the natural enemies of pests, such as pathogenic microorganisms, parasites and predators. Therefore, contemporary forest protection requires the advancement of integrated methods for pest insect and disease control through developing methods of forecasting forest dangers, the use of natural enemies and agro-technical methods for regulation of pests, as well as the development of decision support systems as a tool facilitating introduction of integrated forest protection principles. Such support systems help to establish optimal terms for the implementation of protection measures, so as to increase their efficiency while limiting the use of chemical pesticides to an absolute minimum. 


\section{KeY WORDS}

Drought, water stress, stand weakening, insects, pathogens, plant protection products, invasive species, integrated pest management, forest protection

\section{INTRODUCTION}

Forest management comprises the protection of forests that involves monitoring present and identifying future factors with negative impacts on forest ecosystems, along with applying a range of methods to reduce risks caused by these factors (Szabla and Szujecki 2016). One of the most important issues in contemporary forest protection is the declining health of Poland's stands due to climate change impacts associated with earlier rarely observed extreme weather events, such as heat waves, droughts, heavy rains followed by floods, severe hailstorms, hurricanes and whirlwinds (Allen et al. 2010; Vanguelova 2010). Polish winters are getting warmer, come later in the year and are not as long as they used to be, so the growing season is extended. Systematic impact of extreme weather negatively affects forest health, and as a result, tree stands are massively attacked by harmful insects or severely infected by fungal pathogens.

Air temperature is the most important factor with direct effects on entomofauna. The average temperature increase by $1-2^{\circ} \mathrm{C}$ can lead to changes in insect physiological processes, shorter developmental stages, which can be followed by increased numbers of insect generations in the season, as well as modification of insect dispersal and movement (Netherer and Schopf 2010; Jaworski and Hilszczański 2013). Insects that are secondary pests of forest trees can serve as an example, as climate warming contributes to increasing the number of their generations emerging in the year (Öhrn 2012). On the other hand, high air temperatures (over $30^{\circ} \mathrm{C}$ ) can negatively affect population dynamics by limiting insect fertility and feeding activity (Christiansen and Bakke 1968; Wermelinger and Seifert 1998). Extreme air temperatures can have indirect effects on insect population numbers, such as decreased biological activity of natural enemies, in particular pathogenic bacteria, viruses, fungi and nematodes (Lacey et al. 2015). Furthermore, long-term drought and water deficiency in the soil have adverse effects on host plants, thus - on in- sects as well. Tree root pathogens and saprophytes that break down wood grow better at higher soil temperatures (Sierota and Małecka 2016). Root systems damaged by drought, sudden freezing or as a result of hurricane become the portal of entry for fungal pathogens that initiate the multistage process of tree stand disease, often ending with tree death, in which harmful insects participate actively (Mykhayliv and Sierota 2010).

\section{Dieback of CONIFEROUS StANDS}

Norway spruce Picea abies (L.) H. Karst - a dominant tree species in mountain forests growing in Southern Poland - is particularly sensitive to hydrothermal stress. Long drought periods, prevailing in the last two decades, have exaggerated the Norway spruce forest decline in the Polish mountains (Szabla 2009; Grodzki et al. 2010, 2014). This process was intensified in the summer 2006, when weeks of droughts and extremely high air temperatures in the Beskidy Mts. (western Carpathians) initiated a large-scale process of Norway spruce dieback (Grodzki et al. 2014). Extreme weather favoured expansion of root fungi of the genus Armillaria. Consecutively, fungal pathogen infections lowered the threshold of natural resistance of Norway spruce stands, which as a result were massively colonized by secondary insects, namely bark beetles Ips typographus (L.) and other co-occurring insect species. In 2016, the decline of Norway spruce stands was observed on the total area of over 40.2 thousand ha, and nearly 560,000 $\mathrm{m}^{3}$ of timber was jeopardized (Milewski 2016). In the last decade, the problem has been recorded just in the south of the country (the Forest Districts situated in the Beskid Śląski and Żywiecki Mts.); however, since 2015, it has been also observed in the south-western regions, therefore, sustainability of forest stands in the region of Silesia (in particular - Lower Silesia) has also been threatened.

Prolonged dry periods and high air temperatures, more than ever in July and August 2015, have resulted 
in a rapid decrease of groundwater levels. Even Scots pine Pinus silvestris L. with its taproot system was not able to handle stress due to water deficiency - especially, when it grows on fertile sites. In 2015, Scots pine decline was observed in the total area of over 40 thousand ha, including the area of nearly 1.5 thousand ha, where the Scots pine trees severely colonized by secondary insects or infected by fungal diseases had to be clear-cut (Forest Research Institute 2016). The decline of Scots pine has been increasingly observed in Central and Southern Poland.

Scots pine forests have been continuously damaged by fungal diseases and secondary insects. Steelblue jewel beetle Phaenops cyanea (F.) is placed at the top of the list of pest insects, which colonizes sun-heated forest edges formed due to windbreaks, as well as Scots pine trees located around forest gaps shaped as a result of harvesting or removing specimens attacked by fungal pathogens (Sowińska 2006). In the years 2015-2016, the steelblue jewel beetles affected the Scots pine stands virtually throughout the whole country. The second insect species involved in Scots pine dieback is engraver beetle Ips acuminatus (Gyll.), which is one of the most important pine pests (Siitonen 2014) - very difficult to be detected early enough, as it colonizes only the upper parts of the trunk. Furthermore, I. acuminatus adults are the vector of fungi causing wood sapstain, which translates into the decrease of timber market value. In the years 2015-2016, greater than before occurrence of engraver beetles was observed mainly in Southern and Eastern Poland (nearly 400 ha of Scots pine stands damaged) (Forest Research Institute 2016). Heavily coated in ice trees due to excessive frost, snow or hail can be seriously injured (e.g., broken branches, bent trunks) and then easily colonized by Pissodes spp. weevils (Grègoire and Evans 2004). As regards fungal infections, water balance disorders constitute an important factor favouring the apical die-off of pine shoots - a disease caused by fungi such as Gremmeniell abietina Lagerb., Cenangium ferruginosum Fr. and Sphaeropsis sapinea Fr. Fungal diseases have increasingly impacted trees in a range of Poland's forests, especially those growing in western regions of the country.

In the years 2014-2015, there recurred the problem of larch (Larix spp.) decline. This was particularly intense in North-eastern Poland, on afforested post-agricultural lands, where the ploughing technique used be- fore planting hindered appropriate development of larch seedling roots, which resulted in inadequate formation of mycorrhizas. Larch weakening was observed in Poland's southern regions, in forests harshly affected by large larch bark beetle - Ips cembrae (Heer) (Grodzki 2010). Larch deterioration was also recorded on postfire areas reforested with Larix trees as forecrop - planted densely in the soil degraded by fire. In this case, the most likely reasons behind larch deterioration are insufficient amounts of available nutrients in the soil and needle-infecting fungus Meria laricis Vuill.), which spreads out via adjoining shoots of too densely planted trees (Jalkanen 2016).

\section{Dieback Of Deciduous Stands}

Water stress, and above all, groundwater level decrease have long added to the decline of oak stands. Weakened oaks are colonized easily by secondary pests, such as two-spotted oak borer Agrilus biguttatus (F.), whose mass occurrence may lead to the demise of entire tree stands (Moraal and Hilszczański 2000). Two-spotted oak borer is regularly accompanied by other oak borers, such as Agrilus angustulus (Illiger) and A. sulcicollis Lacordaire (Ranius and Jansson 2000). Outbreaks of geometer moths Geometridae and leafroller moths Tortricidae have also had detrimental effects on oaks (Kerslake et al. 1996). Increased populations of geometer moths were observed in Poland in the years 2011-2013, more than ever in the north-eastern regions of the country. Organisms that damage the fine roots of deciduous trees, especially oaks, are pathogens of the genus Phytophtora and Pythium (Jankowiak et al. 2013). Oak decline has also been observed in Western Poland for many decades (Oszako 2007) - recently in the year 2015 .

Most likely, prolonged droughts initiated the spreading of an infectious disease of ash trees (Fraxinus L.) caused by fungus Hymenoscyphus fraxineus (T. Kowalski) Baral, Queloz \& Hosoya (= Chalara fraxinea) followed by the large-scale decline of ash trees all through Europe (Kowalski 2006; Baral et al. 2014). In 2015, Chalara dieback of ash was recorded in Central, Eastern and Southern Poland (Orzechowski et al. 2016). Due to the lack of effective strategies for managing the disease and large losses, at the beginning of the 2000s, 
the State Forests postponed the ash breeding and planting until the development of useful control methods. At present, the activities on ash regeneration in nurseries and plantations are carried out to a limited extent.

\section{INVASIVE SPECIES}

Global warming increases the probability that pest organisms typical for the regions with higher air temperatures will occur in Poland's forests. An example is Bursaphelenchus xylophilus (Steiner \& Buhrer) - pinewood nematode (PWN) that causes a lethal disease in pine trees in North America, Asia and south-western Europe (Braasch 2001). The nematode is vectored by longhorn beetles of the genus Monochamus (Coleoptera: Cerambycidae) that dwell in pine wood. PWN has not been so far recorded in Poland, however, it is listed as a quarantine pest (Tomalak and Filipiak 2013).

The most important factor in the long-distance spread of PWN between countries and continents is human activity, related to the import of timber and wooden packaging material. In 1999, the nematode was detected in Europe on the territory of Portugal, and then in Spain. Now, over a million hectares of pine stands are PWNinfected (d'Errico et al. 2015). Scots pine is one of the most susceptible species to B. xylophilus infection (Filipiak 2015; Hopf-Biziks et al. 2016). So far, the infected trees have died only in the regions where the average air temperatures in the summer months exceeded $20^{\circ} \mathrm{C}$ (Rutherford and Webster 1987). Studies by Sukovata et al. (2012) indicated that the Scots pine stands in Central Poland, at risk in the case B. xylophilus, entered Poland.

European ashes, including those growing in Poland (mainly common ash Fraxinus excelsior L. and green ash $F$. pennsylvanica Marsh.) are threatened by emerald ash borer Agrilus planipennis Fairmaire, detected in the European part of Russia (near Moscow) in 2007 (Orlova- Bienkowskaja 2014). At present, almost all ash trees in Moscow and around have already been killed or severely damaged by this pest. It is estimated that emerald ash borer disperses at a rate of 30 to $40 \mathrm{~km} / \mathrm{year}$, mainly using transportation means, as it occurs in tree stands located along highways, in particular - motorways.

A real risk associated with warming climate is the likelihood of massive occurrence of pine processionary Thaumetopoea pityocampa Den. \& Schiff. in Poland.
This pest occurs commonly in North Africa and southern Europe (Portugal, Spain, France, Greece, Turkey, Hungary) and threatens the Pinus spp. forests, including the Scots pine stands (Hòdar et al. 2003). Thus far, in Poland, there has sporadically been recorded another hazardous species of the genus Thaumetopoea, that is, T. pinivora Treitschke, who co-occurs with other folivore pests, such as nun moth Lymantria monacha L. (Hòdar et al. 2016). In 2015, increased populations of T. pinivora were recorded in forests of Western Poland. Thaumetopoea larvae also pose a significant threat to humans as utricant hairs that fall off the processionary caterpillars have strong allergenic properties and cause severe itching, rash and mucositis (Bonamonte et al. 2013). These symptoms may occur not only after a direct contact with caterpillars, but also after touching their cocoons or sites where these gregarious larvae passed by in a characteristic single file.

\section{Considerably feWer Plant PROtection PRODUCTS REGISTERED FOR FORESTRY}

Starting from the 1990s, in the European Union, there has significantly changed legislation with regard to the placing of plant protection products on the market and their authorization in the Member States (Matyjaszczyk 2011; Skrzecz 2013). In order to harmonize the law, the criteria for approval of new active substances for the use in the EU have also been changed so that only active substances authorized by the European Commission based on a common procedure can be included on the market. The changes were initiated by the Council Directive of 15 July 1991 providing for rules governing plant protection products and the active substances contained in those products (91/414/EEC), which pointed out that the protection of people, animals and the environment takes precedence over improvement in the level of agricultural production (Matyjaszczyk 2008). By virtue of this legal act, all the active substances on the market were subjected to a 4-stage review, that is, a re-assessment and documenting that they do not pose any threat to human health and environment. The producers of active substances were charged with high costs of the review. The new law as regards the use of pesticides in the EU led to the elimination of numerous active substances from the market. Consequently, there 
were banned plant protection products containing the substances rendered hazardous to humans and the environment, including pesticides with long-term persistence and those adversely affecting pollinators (Matyjaszczyk 2007). The most rigorous criteria concerned insecticides, which, due to their mode of action, were classified as more toxic when compared to other plant protection products. At the same time, costly review procedures forced the small producers to withdraw their plant protection products from the market, as the sale could not cover the expenditures to be incurred for the re-evaluation of the active substances so far used. This concerned not only plant protection products applied on small areas, such as biological preparations. A range of products earlier approved for the protection of large-scale crops was also significantly narrowed. Thus, nearly $70 \%$ products used before in the protection of Poland's forests (a small area when compared to that of agricultural crops) disappeared from the market as their registration was unprofitable (Karmiłowicz et al. 2017) (Fig. 1).

New legislation now in force is Regulation (EC) No $1107 / 2009$ of the European Parliament and of the Council of 21 October 2009 concerning the placing of plant protection products on the market and repealing Council Directives 79/117/EEC and 91/414/EEC. The Regula- tion comprises harmonized rules on the marketing, use and control of the use of plant protection products and emphasizes the precautionary principle that industry demonstrates that substances or products produced or placed on the market do not have any harmful effect on human or animal health or any unacceptable effects on the environment'. The regulation allows for submitting application for an extension of the authorization of a plant protection product registered in a given Member State for minor use (Matyjaszczyk 2012). Hence, in recent years the State Forests have obtained the consent to use a dozen or so fungicides and insecticides in crops cultivated on small areas, that is, in nurseries, seed plantations and reforestation/afforestation areas (Głowacka and Perlińska 2015). Directive 2009/128/EC of the European Parliament and of the Council of 21 October 2009 establishing a framework for Community action to achieve the sustainable use of pesticides introduced a ban on the use of plant protection products with agricultural machinery, except for situations when such application brings benefits in the form of reducing the impact of pesticides on human health and the environment or alternative methods are not available. In 2016, there were 35 pesticides (insecticides and fungicides) at the disposal of the State Forests, of which 3 were approved by Poland's Ministry of Agriculture and Rural

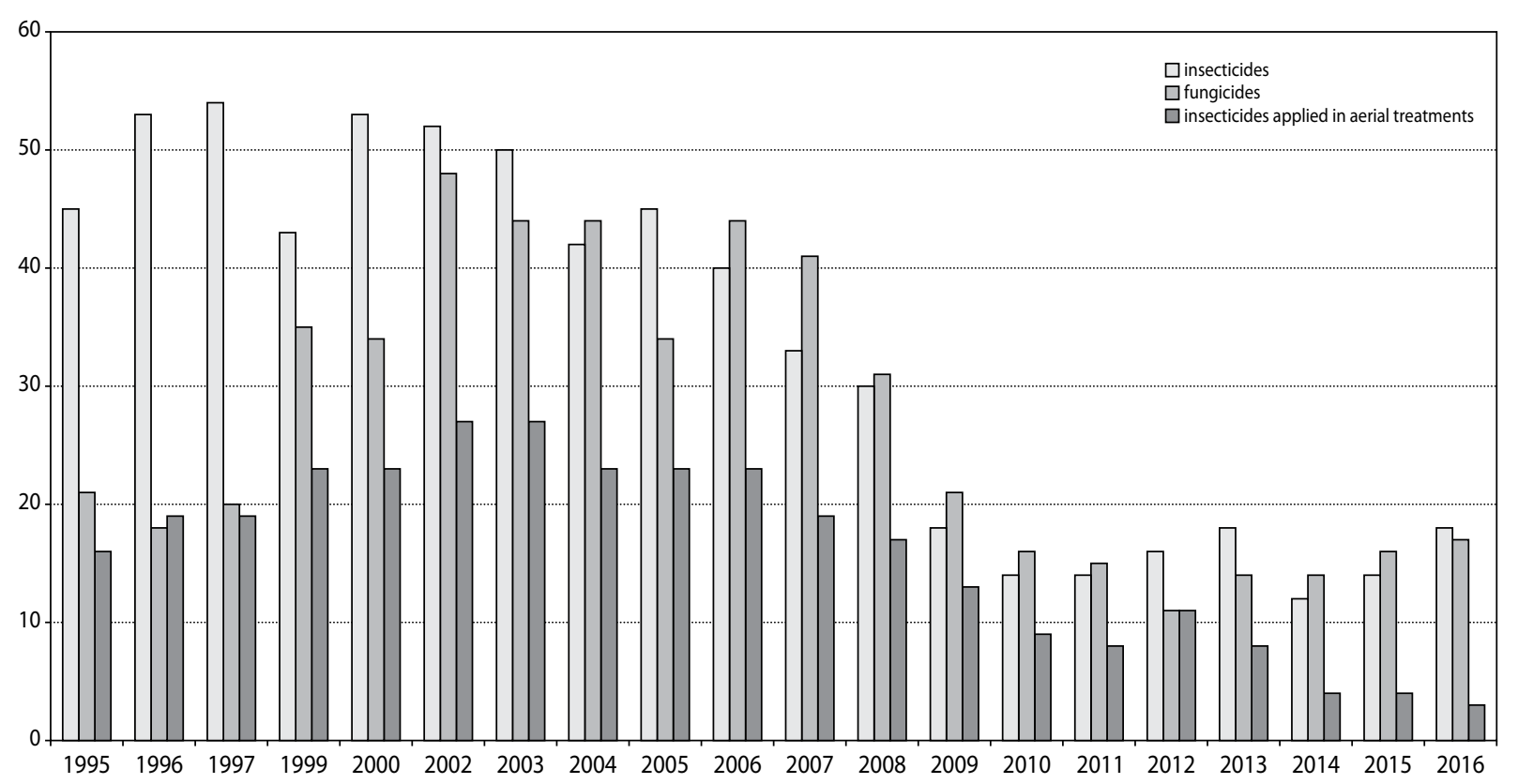

Figure 1. Numbers of insecticides and fungicides registered in Poland for use in forestry in the years 1995-2016 
Development for the use in agrotechnical procedures. The active substances of the allowed products are: chitin synthesis inhibitor diflubenzuron (Dimilin $480 \mathrm{SC}$ ), neonicotinoid acetamiprid (Mospilan 20 SP) and bacterium Bacillus thuringiensis (Foray 76 B) (Głowacka et al. 2016).

Further restrictions on the use of plant protection products in the State Forests result from FSC certification scheme (Głowacka and Perlińska 2015). Forest Stewardship Council (FSC) is an international organization promoting forest management through a certification system granted to the forest management units operating in an environmentally, economically and socially responsible way. FSC has developed exceptionally preventive criteria for the assessment of pesticides and prepared the list of highly hazardous and prohibited products. Thus, in certified forests, the use of most insecticides and fungicides earlier registered in Poland has been banned, and this virtually made it impossible to apply chemical treatments against pests (insects and fungi) in Poland's forests. On the other hand, the FSC Pesticide Policy allows for submitting application under the FSC Pesticide Derogation Procedure for temporary derogation to use pesticides that FSC has identified as 'highly hazardous' (HHP). The derogation is issued for a period of 5 years, during which time, the certificate holder is obliged to look for alternative means to fight pests.

\section{IMPLEMENTATION OF INTEGRATED FOREST PROTECTION}

As of 1 January 2014, the Act of 8 March 2013 on plant protection products - adopted with the aim to incorporate the EU's law (Directive 2009/128/EC and Regulation 1107/2009) into Polish legislation - lays down obligations relating to the integrated plant protection (IPP) on all professional users of pesticides. IPP focuses on the plant (e.g., tree) with its features and associations with the environment as the main target of any treatment undertaken (Otvos 2004). A very important element of integrated forest protection (IFP) is prophylaxis joined with agrotechnical and silvicultural methods enhancing pest resistance in trees, as well as reducing the risk of pest attack. Another important aspect is the Decision Support System (DSS, a multi-stage decision process), which helps to undertake appropriate protection procedures - based on the evaluation of the population numbers of a given pest and associated pest organisms, damage identification/prediction, as well as estimation of losses due to the failure to undertake an emergency procedures (economic analysis) (Tracz 2001). DSS supports the decisions on the optimal timing for the application of protective measures so as to achieve their highest effectiveness and, at the same time, to limit the use of chemical pesticides to the necessary minimum. In the integrated forest protection, biological methods take precedence that include not only the use of biological insecticides, but also the protection of pest natural enemies (by maintaining their appropriate habitat conditions). Chemical treatments are the socalled 'emergency', used after exhausting other methods and under the conditions threatening the durability of crops (Pruszyński 2012). The necessity to implement IFP justifies the development of new methods based on the biological control agents, that is, insect natural enemies, such as pathogens (bacteria, fungi, viruses) and macroorganisms (insecticide nematodes, predators and parasitoids). In Poland, studies have also been carried out on insect pheromones and kairomones in an attempt to improve monitoring of pest insect populations.

\section{Cyclically occurring outbreaks OF LEAF-EATING INSECTS}

One of the most important problems concerning forest protection are cyclical outbreaks of insects - for the most part, those leaf-eating. In Poland's coniferous stands, most commonly recorded folivores are: nun moth, (Lymantria monacha L.), pine-tree lappet Dendrolimus pini (L.), pine beauty Panolis flammea Den. $\&$ Schiff. and conifer sawflies Diprionidae. In deciduous tree stands, oak pests prevail, which are from the families Geometridae and Tortricidae plus cockchafer Melolontha spp. adults (Szujecki 1987). Over the past 50 years, Poland's forest have experienced many outbreaks of leaf-eating insects - from that pandemic of nun moth at the turn of the 1970s and 1980s, with protective treatments carried out on the area of over 2 million hectares (Fig. 2) to outbreaks of various folivore insects treated on dozen or so thousand ha (Schönherr 1985, Jabłoński 2015). Due to the fact that the outbreak of one insect species is most often followed by the oc- 


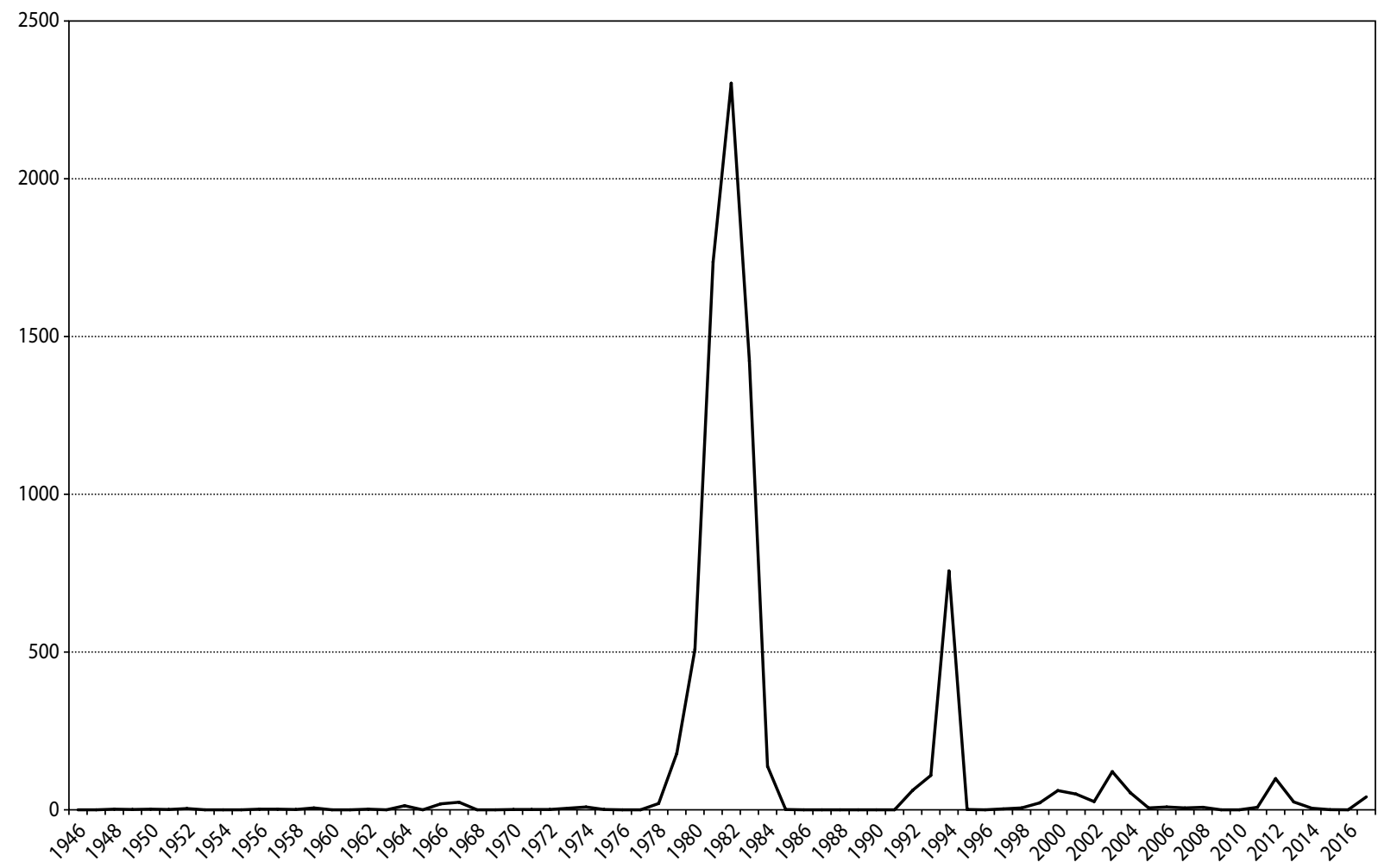

Figure 2. Area (thousands of ha) of nun moth control in the years 1946-2017

currence of increased populations of another pest species, in Poland's forests, control measures are annually applied on at least several tens of thousands ha of affected forests. Most often, this concerns co-occurrence or succeeding incidence of nun moth, pine-tree lappet, pine beauty and conifer sawflies (Fig. 3). In view of the above, next to improving the forest protection measures, it is necessary to constantly observe populations of the most important folivore insects using advanced monitoring techniques for accurate estimation of their population numbers.

\section{Other Issues}

Reduction of the numbers of Melolontha spp. grubs in forest soils has remained an unresolved problem of forest protection (Malinowski 2007; Sukovata et al. 2015a). Mospilan 20 SP at a dose of 0.41 per 1 ha is registered insecticide to control cockchafer adults. (Głowacka and Sierpińska 2012). In general, the majority of insecticides to control grubs was withdrawn from the market due to their negative impacts on the soil environment. Currently, foresters have no insecticide for protecting nurseries and crops against grubs. This forces the practitioners to look for alternative solutions; hence, they attempt to use jute sacks so as to protect seedling roots, as well as various types of barriers buried along nursery edges to hamper grub migration from adjacent tree stands (Woreta 2015). Studies undertaken presently focus on the use of grub natural enemies, including fungus Beauveria brongniartii and insecticidal nematodes (Kreft et al. 2012; Sierpińska et al. 2015). Nonetheless, the results obtained so far indicate weak effects of natural enemies on grub population numbers. Other studies were carried out on the effects of repellent plants, and the results obtained by Skrzecz et al. (2014) and Sukovata et al. (2015b) showed that brown mustard (Brassica juncea (L.) Czern.) had repellent effects on the youngest developmental stages of grubs (especially in the case of forest cockchafer Melolontha hippocastani). Niemczyk et al. (2017) showed an extremely important role of environmental factors and silvicultural practice in forest ecosystems threatened by common (M. melolontha) and 


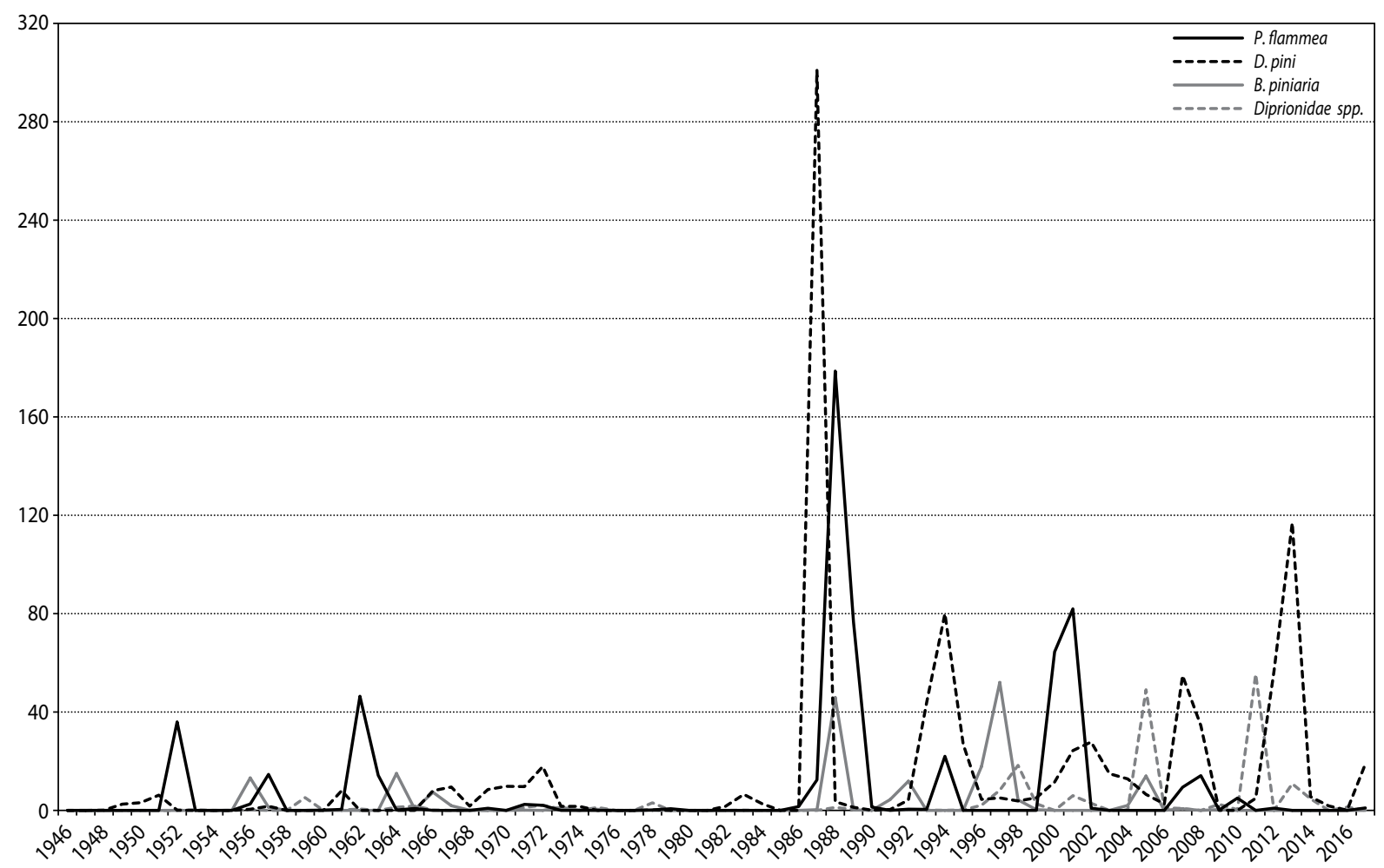

Figure 3. Area (thousands of ha) of control of Panolis flammea, Bupalus piniaria, Dendrolimus pini and Dipriondae spp. in the years 1946-2014

forest ( $M$. hippocastani) cockchafers. The development of effective methods of reducing cockchafer populations requires improvement in monitoring by including examination of changes in grub population size at permanent observation points, as well as assessments of grub spatial distribution within the most threatened areas. It is also necessary to refine the method for determination of the start and culmination of adult cockchafer swarming, which is of great importance in planning protective measures.

Up till now, no coherent strategy has been developed to protect Poland's seed orchards, especially the coniferous orchards, which are often attacked by seed and cone pests, who reduce yielding efficiency, and thus - seed harvest (Bystrowski and Wójcik 2009). These problems occur mainly in seed orchards in Eastern Poland. In larch plantations, severe losses are caused by the maggots Strobilomyia spp., whose larvae feed on seeds inside the cones (Michelsen 1988). Maggots can colonize even up to $80 \%$ cones and cause severe losses - especially in the years of low and medium seed productivity (Seifert et al. 2000). No successful program including IFP principles has yet been implemented in Poland's seed orchards. In order to develop a suitable strategy, all cone pest insect species should be identified, then the gaps in knowledge on their biology in view of tree phenology should be filled. At the same time, there should be developed the methods based on pheromone baited traps to assess and forecast seed orchard risks due to pest insects. The integrated forest protection implemented in seed orchards also requires the development of efficient control methods, which is an extremely difficult task, due to the fact that the most important seed orchard pests endure hidden in the cones. However, thanks to the inclusion of seed orchards into the group of 'minor crops', it is possible to extend an assortment of plant protection products possible to use to protect seeds and cones against harmful insects.

Another important issue in forest protection is damage caused by game animals (Bobek et al. 1994). The importance of this problem can be illustrated by the annual expenditures incurred on preventing the wildlife damage in Poland's forest stands. Since 2010 the total annual cost of the activities in this area has already ex- 
ceeded 100 million PLN and reached 157 million PLN in 2015 (Kruk and Kornatowska 2014; Milewski 2016). In order to limit the damage due to game animals, a range of methods for protecting seedlings and young trees have been applied, including chemical protection of individual trees (application of repellents) and mechanical protection (various types of casings and tubes for individual trees or fencing young plantations). Each year, on average, about 90 thousand ha of Poland's forests are subjected to various forms of protection against game damage. The most common measure is the use of repellents and about $2 / 3$ of the area of young or older plantations under protection treatments is secured against game using this method.

\section{Conclusions}

The most important problems of forest protection in Poland result primarily from deteriorated health condition of forest stands as a result extreme weather events due to climate change. Extreme weather disturbs the stand spatial order and negatively affects the forest trees, which are massively attacked by pest insects and fungal pathogens. Long lasting droughts that have prevailed in Poland in the recent decades have become one of the most important agents that triggered the large-scale process of Norway spruce dieback in Southern Poland. In 2015, extremely high air temperatures and drought caused a rapid decrease in groundwater levels in forest habitats, followed by Scots pine decline. Stress resulting from disturbances in water supply negatively affected deciduous trees, and especially oaks. Most likely, long drought has initiated the development of infectious disease of ash trees all through the country. Additionally, climate warming increases the probability of invasive occurrence of alien pest insects and fungal pathogens typical of areas with higher temperatures.

The most urgent issues in the protection of Poland's forests include:

- Counteracting the decline of coniferous and deciduous forests and threats posed by pest insects and fungal pathogens, especially in the areas affected by large-scale disasters.

- Monitoring the changes in assemblages of harmful insects and fungal pathogens due to climate change, counting cyclical outbreaks of pine folivore.
- Improving non-chemical methods of forest protection and developing decision support systems as part of the integrated management of pest insects and pathogens in forests.

- Improving measures to control cockchafer populations in nurseries and plantations.

- Improving measures to control insects harmful to seeds and cones in seed orchards.

- Protecting forests against game damage.

\section{References}

Allen, C.D., Macalady, A.K., Chenchouni, H. et al. 2010. A global overview of drought and heat-induced tree mortality reveals emerging climate change risks for forests. Forest Ecology and Management, 259, 660-684. DOI: 10.1016/j.foreco.2009.09.001.

Baral, H.-O., Queloz, V., Hosova, T. 2014. Hymenoscyphus fraxineus, the correct scientific name for the fungus causing ash dieback in Europe. IMA Fungus, 5 (1), 79-80.DOI: 10.5598/imafungus.2014.05.01.09.

Bobek, B., Perzanowski, K., Kossak, S. 1994. The systems of managing wildlife and forest in central Europe. The Forestry Chronicle, 70 (5), 550-554.

Bonamonte, D., Foti, C., Vestita, M., Angelini, G. 2013. Skin reactions to pine processionary caterpillar Thaumetopoea pityocampa Schiff. The Scientific World Journal. DOI: 10.1155/2013/867431.

Braasch, H. 2001. Bursaphelenchus species in conifers in Europe: distribution and morphological relationship. EPPO Bulletin, 31, 127-142.

Bystrowski, C., Wójcik, G. 2009. Use of neonicotinoid insecticides for the protection of pedunculate oak (Quercus robur L.) acorns in the seed orchard in the Leżajsk Forest District. Leśne Prace Badawcze, 70 (3), 271-275. DOI: 10.2478/v10111-009-0024-z.

Christiansen, E., Bakke, A. 1968. Temperature preference in adults of Hylobius abietis L. (Coleoptera, Curculionidae) during feeding and oviposition. Zeitschrift für Angewandte Entomologie, 62, 83-89. d'Errico, G., Carletti, B., Schroeder, T., Mota, M., Vieira, P., Roversi, P.F. 2015. An update on the occurrence of nematodes belonging to the genus Bursaphelenchus in the Mediterranean area. Forestry, 88, 509 -520. DOI:10.1093/forestry/cpv028. 
Filipiak, A. 2015. Pathogenicity of selected isolates of the quarantine pinewood nematode Bursaphelenchus xylophilus to Scots pine (Pinus sylvestris L.). Journal of Plant Protection Research, 55 (4), 378-382. DOI: 10.1515/jppr-2015-0050.

Głowacka, B., Sierpińska, A. 2012. Control of adult cockchafers Melolontha spp. with Mospilan 20 SP. Folia Forestalia Polonica, Series A - Forestry, 54 (2), 109-115.

Głowacka, B., Perlińska, A. 2015. Conditions and perspectives of the reduction of mass insect occurrences in the State Forests (in Polish). Postępy Techniki w Leśnictwie. 132, 32-39.

Głowacka, B., Kolk, A., Janiszewski, W., Rosa-Gruszecka, A., Pudełko, M., Łukaszewicz, J. 2016. Plant protection products, biocides and products for the stump decomposition recommended for the use in forestry in 2016 (in Polish). Available at: http:// www.lasy.gov.pl/publikacje/copy_of_gospodarkalesna/ochrona_lasu/srodki-ochrony-roslin/Aktualizacja2_2016-01-22.pdf.

Grègoire, J.-C., Evans, H.F. 2004. Damage and control of BAWBILT organisms - an overview. In: Bark and wood boring insects in living trees (eds.: F. Lieutire, K.R. Day, A. Battisti, J.-C. Gregoire, H.F. Evans). Springer, The Netherlands, 19-38.

Grodzki, W. 2010. Possibility of the reduction of Ips cembrae (Heer) (Coleoptera, Curculionidae, Scolytinae) populations in larch stands in southern Poland (in Polish with English summary). Sylwan, 154, 3, 160-167.

Grodzki, W., Turčáni, M., Jakuš, R., Hlásny, T., Raši R., McManus M.L. 2010 Bark beetles in the Tatra Mountains. International research 1998-2005 - an overview. Folia Forestalia Polonica, Series A Forestry, 52 (2), 114-130.

Grodzki, W., Starzyk, J.R., Kosibowicz, M. 2014. Variability of selected traits of Ips typographus (L.) (Col.: Scolytinae) populations in Beskid Żywiecki (Western Carpathians, Poland) region affected by bark beetle outbreak. Folia Forestalia Polonica, Series A - Forestry, 56 (2), 79-92. DOI: 10.2478/ ffp-2014-0008.

Hopf-Biziks, A. Schröder, T. Schütz, S. 2016. The pine wood nematode, Bursaphelenchus xylophilus (Steiner \& Buhrer) Nickle, and its pathogenicity to German Pinus sylvestris provenances. Journal of Plant Diseases and Protection, 123 (1), 43-49. DOI: $10.1007 / \mathrm{s} 41348-016-0005-4$.

Hòdar, J.A., Cassel-Lundhagen, A., Battisti, A., Larsson, S. 2016. A little further south: Host range and genetics of the Northern pine processionary moth, Thaumetopoea pinivora (Lepidoptera: Notodontidae) at the southern edge of its distribution. European Journal of Entomology, 113, 200-206. DOI: 10.14411/eje.2016.024.

Hòdar, J.A., Castro, J., Zamora, R. 2003. Pine processionary caterpillar Thaumetopoea pityocampa as a new threat for relict Mediterranean Scots pine forests under climatic warming. Biological Conservation, 110, 123-129.

Forest Research Institute. 2016. Short-term forecast of occurrence of most important pests and diseases of forest trees in 2016 (in Polish). Forest Research Institute, Analyzes and Reports no. 28.

Jabłoński, T. 2015. Occurrence and control of forest defoliatore - trends and forecasts (in Polish). Postępy Techniki w Leśnictwie, 132, 13-19.

Jalkanen, R. 2016. Synthesis and New Observations on Needle Pathogens of Larch in Northern Finland. Forests, 7 (1), 25. DOI: 10.3390/f7010025.

Jankowiak, R., Banach, J., Balonek, A. 2013. Susceptibility of Polish provenances and families of pedunculate oak (Quercus robur L.) to colonisation by Phytophthora cambivora. Leśne Prace Badawcze, 74 (2), 161-170.

Jaworski, T., Hilszczański, J. 2013. The effect of temperature and humidity changes on insects development and their impact on forest ecosystems in the context of expected climate change. Leśne Prace Badawcze, 74, 345-355. DOI: 10.2478/frp-2013-0033.

Karmiłowicz, E., Skrzecz, I., Matyjaszczyk, E. 2017. Changes of active substances and their formulations used by aerial spraying in the protection of Polish forests against harmful insects (in Polish with English summary). Przemyst Chemiczny, 96/12, 1000-1003. DOI: 10.15199/62.2017.12.8.

Kerslake, J.E., Kruuk, L.E.B., Hartley, S.E., Woodin, S.J. 1996. Winter moth (Operophtera brumata (Lepidoptera: Geometridae)) outbreaks on Scottish heather moorlands: effects of host plant and parasitoids on larval survival and development. Bulletin of Entomological Research, 86 (2), 155-154. DOI: $10.1017 / \mathrm{S} 0007485300052391$. 
Kowalski, T. 2006. Chalara fraxinea sp. nov. associated with dieback of ash (Fraxinus excelsior) in Poland. Forest Pathology, 36, 264-270. DOI: 10.1111/j.14390329.2006.00453.x.

Kreft, A., Kazimierczak, W., Sierpińska, A., Skrzypek, H., Skrabucha, A., Dybała, M., Dźwierzyńska M. 2012. Characteristics of Winter moth (Operophtera brumata (Lepidoptera: Geometridae)) outbreaks on Scottish heather nematodes isolated from the grubs of Melolontha sp. (Coleoptera: Scarabaeidae) (in Polish with English summary). Progress in Plant Protection/Postepy w Ochronie Roślin, 52 (4), 1093-1097.

Kruk, H., Kornatowska, B. 2014. Sustainable forest management in Poland - theory and practice. Folia Forestalia Polonica, Series A - Forestry, 56 (1), 45-55. DOI: 10.2478/ffp-2014-0005.

Lacey, L.A., Grzywacz, B., Shapiro-Ilan, D.I., Frutos, R., Brownbridge, M., Goettel, M.S. 2015. Insect pathogens as biological control agents: Back to the future. Journal of Invertebrate Pathology, 132, 1-41. DOI: 10.1016/j.jip.2015.07.009.

Malinowski, H. 2007. Current problems of forest protection related to the control of cockchafers (Melolontha spp.) (in Polish with English summary). Progress in Plant Protection/Postępy w Ochronie Roślin, 47 (1), 314-322.

Matyjaszczyk, E. 2007 Impact of accession to the European Union on selected aspects of the Polish market of plant protection chemicals (in Polish with English summary). Progress in Plant Protection/ Postęyy w Ochronie Roślin, 47 (1), 72-78.

Matyjaszczyk, E. 2008. Placing plant protection products on the Polish market with regard to the registration of individual formulations. Annales Universitatis Mariae Curie-Skłodowska Lublin - Polonia. Sectio E, 63 (2), 60-66.

Matyjaszczyk, E. 2011. Registration of plant protection products in Poland - the history, present state and future (in Polish with English summary). Progress in Plant Protection/Postępy w Ochronie Roślin, 51 (1), 77-87.

Matyjaszczyk, E. 2012. Current possibilities of selected minor crops protection in Poland and other European Union countries (in Polish with English summary). Progress in Plant Protection/Postepy w Ochronie Roślin, 52 (1), $167 \square 173$.
Michelsen, V. 1988. A world revision of Strobilomyia gen.n.: the anthomyiid seed pests of conifers (Diptera: Anthomyiidae). Systematic Entomology, 13, 271-314. DOI: 10.1111/j.1365-3113.1988.tb00244.x.

Milewski, W. (ed.) 2016. Forests in Poland - 2016. http:// www.lasy.gov.pl/pl/informacje/publikacje/in-english/forests-in-poland/forests-in-poland-2016.

Moraal, L.G., Hilszczański, J. 2000. The oak buprestid beetle, Agrilus biguttatus (F.) (Col., buprestidae), a recent factor in oak decline in Europe. Journal of Pest Science, 73 (5), 134-138.

Mykhayliv, O., Sierota, Z. 2010. Threat caused to forests by the root rot Heterobasidion annosum (Fr.) Bref. in relation to soil temperature and precipitation. Leśne Prace Badawcze, 71 (1), 51-59. DOI: 10.2478/v10111-010-0003-4.

Netherer, S., Schopf, A. 2010. Potential effects of climate change on insect herbivores in European forests - general aspects and the pine processionary moth as specific example. Forest Ecology and Management, 259, 831-838.

Niemczyk, M., Karwański, M., Grzybowska, U. 2017. Effect of environmental factors on occurrence of cockchafers (Melolontha spp.) in forest stands. Baltic Forestry, 23 (2), 334-341.

Orzechowski, M., Kacprzak, J., Kędziora, W. 2016. Dying of ash (Fraxinus excelsior L.) in the Jesionowe Góry Nature Reserve. Leśne Prace Badawcze, 77 (2), 124-133. DOI: 10.1515/frp-2016-0014.

Orlova-Bienkowskaja, M. 2014. Ashes in Europe are in danger: the invasive range of Agrilus planipennis in European Russia is expanding. Biological Invasions, 16 (7), 1345-1349. DOI: 10.1007/s10530-0130579-8.

Oszako, T. 2007. Causes of oak stand decline (in Polish with English summary). Sylwan, 6, 62-72.

Otvos, I.S. 2004. Integrated pest management in forestry: potential and challenges. In: Integrated pest management: potential, constraints and challenges (eds.: O. Koul, G.S. Dhaliwal, G.W. Cuperus). CABI Books, 205-254. DOI: 10.1079/9780851996868.0000.

Öhrn, P. 2012. The spruce bark beetle Ips typographus in a changing climate - effects of weather conditions on the biology of Ips typographus. Pd.D. Thesis. Swedish University of Agricultural Sciences, Uppsala. 
Pruszyński, G. 2012. Chemical plant protection product in integrated pest management (in Polish with English summary). Progress in Plant Protection/ Postępy w Ochronie Roślin, 52 (4), 1204-1209.

Ranius, T., Jansson, N. 2000. The influence of forest regrowth, original canopy cover and tree size on saproxylic beetles associated with old oaks. Biological Conservation, 95 (1), 85-94.

Rutherford, T.A., Webster, J.M. 1987. Distribution of pine wilt disease with respect to temperature in North America, Japan, and Europe. Canadian Journal of Forest Research, 17 (9), 1050-1059.

Schönherr, J. 1985. Nun moth outbreak in Poland 1978-1984. Journal of Applied Entomology, 99 (1/5), 73-76. DOI: 10.1111/j.1439-0418.1985.tb01963.x.

Seifert, M., Wermelinger, B., Schneider, D. 2000. The effect of spruce cone insects on seed production in Switzerland. Journal of Applied Entomology, 124, 269-278.

Sierota, Z., Małecka, M. 2016. Threats to forests from fungal pathogens and weather extremes (in Polish). Postępy Techniki w Leśnictwie, 132, 20-24.

Sierpińska, A., Popowska-Nowak, E., Bednarek, A. 2015. Beauveria brongniartii Sacc. (Petch) against grubs of Melolontha spp. in forest nurseries with different soil pH. Folia Forestalia Polonica, Series A - Forestry, 57 (4), 210-217. DOI: 10.1515/ffp-2015-0021.

Siitonen, J. 2014. Ips acuminatus kills pines in southern Finland. Silva Fennica, 48 (4), article id 1145.

Skrzecz, I. 2013. Prospects for the use of plant protection products in forestry - law and practice (in Polish). Postępy Techniki w Leśnictwie, 123, 7-14.

Skrzecz, I., Sowińska, A., Janiszewski, W. 2014. Effects of botanical antifeedants on Melolontha melolontha grub feeding on Scots pine roots. Folia Forestalia Polonica, Series A - Forestry, 56 (3), 135-140. DOI: 10.2478/ffp-2014-0014.

Sowińska, A. 2006. Biology and ecology of steelblue jewel beetle Phaenops cyanea (F.) (Col., Buprestidae) - current state of knowledge (in Polish). Leśne Prace Badawcze, 3, 83-98.
Sukovata, L., Kolk, A., Jaworski, T., Plewa, R. 2012. The risk of pine wilt disease in Poland. Folia Forestalia Polonica, Series A - Forestry, 54 (1), 42-47.

Sukovata, L., Jaworski, T., Karolewski, P., Kolk, A. 2015a. The performance of Melolontha grubs on the roots of various plant species. Turkish Journal of Agriculture and Forestry, 39, 107-116. DOI: 10.3906/tar-1405-60.

Sukovata, L., Jaworski, T., Kolk, A. 2015b. Efficacy of Brassica juncea granulated seed meal against Melolontha grubs. Industrial Crops and Products, $70,260-265$.

Szabla, K. 2009. Current state of spruce stands in Beskids and their genesis [in Polish]. Prace Komisji Nauk Rolniczych, Leśnych $i$ Weterynaryjnych, 11, 13-43.

Szabla, K., Szujecki, A. 2016. In search of a prospective concept of forest protection (in Polish). Studia $i$ Materialy CEPL $w$ Rogowie, 46 (1), 22-31.

Szujecki, A. 1987. Ecology of forest insects. Dr W. Junk Publishers and PWN-Polish Scientific Publishers.

Tomalak, M., Filipiak, A. 2013. Inter-specific competition of Bursaphelenchus xylophilus with native populations of B. mucronatus in pine. In: Pine Wilt Disease Conference (ed.: T. Schröder), 70-71. Braunschweig.

Tracz, W. 2001. Modern tools supporting the decisionmaking process in forestry (in Polish with English summary). Sylwan, 145 (2), 39-47.

Vanguelova, E. 2010. Forest Protection in Europe. Science for environment policy. Available at: http:// ec.europa.eu/environment/integration/research/ newsalert/pdf/23si_en.pdf.

Wermelinger, B., Seifert, M. 1998. Analysis of the temperature dependent development of the spruce bark beetle Ips typographus (L.) (Col., Scolytidae). Journal of Applied Entomology, 122, 185-191.

Woreta, 2015. Control of cockchafer Melolontha spp. grubs - a review of methods. Folia Forestalia Polonica, Series A - Forestry, 57 (1), 33-41. DOI: 10.1515/ffp-2015-0005. 